\title{
HOOFPROBLEME VAN DIE FILOSOFIE EN DIE TEOLOGIE VAN DIE GESKIEDENIS
}

\author{
deur
}

\author{
Prof. P. S. DREYer
}

Ons tema voer ons 'n besonder ingewikkelde veld binne. Dis is die terrein waar filosofie en teologie elkeen afsonderlik historiese verskynsels is en daarom self deel van die historiese verloop is, maar tegelykertyd uit hulle aard oor die geskiedenis besin. Die term "geskiedenis" is egter dubbelsinnig: dit beteken geskiedenis-as-verlede-werklikheid maar ook geskiedenis-aswetenskap. Die geskiedenis-as-wetenskap het die geskiedenisas-verlede-werklikheid tot voorwerp van studie. Die probleme is so ingewikkeld omdat filosofie en teologie nie net historiese verskynsels is nie en nie net oor die geskiedenis-as-verlede-werklikheid besin nie, maar daarmee ook met mekaar en met die geskiedenis-as-wetenskap in verhouding tree.

Ons wil die hoofsake van hierdie problematiek as volg aandui :

\section{Die Gemoeidheid van die Filosofie met die Geskiedenis :}

Filosofie is die rasionale, universele en radikale deurdenking van die werklikheid van menslike eksistensie gesitueerd in 'n bepaalde werklikheid. Hierdie formulering van die aard van die wysbegeerte bring onmiddellik die wesenlike historisiteit van die mens na vore. ${ }^{1}$ ) Met die wesenlike historisiteit van die mens beklemtoon ons dat menslike bestaan altyd tydelike bestaan is - die mens is altyd geworpe in 'n bepaalde tydstip van die geskiedenis; soiets as ' $n$ bowe-tydelike of buite-tydelike menslike bestaan is daar eenvoudig nie en die een wat hom met soiets probeer besighou, is met ' $n$ hersenskim besig. In die bewussyn van sy tydelikheid is die mens egter wesenlik toekomsgerig: hy is gedurig besig om sy hede te transendeer die toekoms in, om sy toekoms te ontwerp, om sy lewe en wêreld te herontwerp en te herbeplan in die lig van wat hy meen hierdie lewe en wêreld behoort te wees. Die transendensie van die hede die toekoms in impliseer egter die verlede, omdat die hede nie los van die

1) Cf. Martin Heidegger, Sein und Zeit, Erste Hälte, 2. Aufl.. Max Niemeyer Verlag, Halle a.d. S., 1929: Gerhard Bauer, "Geschictlichkeit". Wege und Irrwege eines Begriffs, Walter de Gruyter, s.a. (Die kleinen de-Gruyter Bände/Band 3, Copyright 1963). 
verlede is nie en die hede is wat uit die verlede kom. Die mens is daarom ook gedurig met die verlede besig, omdat daaruit sy eksistensiële plekbepaling ${ }^{2}$ ) moontlik is, waarvandaan hy sy toekoms ontwerp, sodat hy vanuit hierdie ontwerp sy leefswêreld van die hede met die oog op die toekoms en gehoorsaam aan bepaalde waardes en norme afbreek en herbou, bewaar en verder bou. Die mens is dus nie 'n wese wat geskiedenis of kultuur het soos wat hy 'n baard kan hê of nie kan hê nie, maar in 'n baie wesenlike sin is die mens geskiedenis en kultuur. Daaruit is dit duidelik dat geskiedenis in die wydste sin van die woord 'n sentrale plek in dia besinning van die mens oor homself en sy wêreld moet inneem.

\section{Die Gemoeidheid van die Teologie met die Geskiedenis :}

Vir ons doel is dit genoeg om te stel dat die teologie 'n groep wetenskappe is wat uitgaan van die veronderstelling van die geloof in die openbaring van God in die Bybel en daarom die Bybel tot doel en voorwerp van studie het; vanuit die Bybel tree die teologie die wêreld binne, maar word in hierdie intrede deur die Bybel gelei, bepaal en begrens. Wanneer ons van geloof praat, impliseer ons reeds kerk, omdat die geloof gewek en in stand gehou word deur die werking van die Heilige Gees in en met die verkondiging van die Woord en die bediening van die sakramente. Die teologie staan dus nie los van die kerk nie, maar is 'n wetenskapsbeoefening vanweë die kerk en terwille van die kerk en is gerig daarop om uit te mond in die verkondiging van die Evangelie deur die kerk.

Die belangrikheid van die geskiedenis as teologiese probleem spring in die oog as ons op die volgende let:

1. Die Ou Testamentiese wet en profete is nie 'n tydlose leer wat in vacuo bestaan nie, maar is self historiese gebeurtenisse wat in 'n bepaalde historiese verloop ingebed is. Die inhoud van wet en profete het grootliks die karakter van verkondiging, oproep en gebod wat 'n geldigheid besit wat oneindig verder strek as die bepaalde historiese gesitueerdheid, maar vir die verstaan van wet en profete is die verstaan van die historiese gesitueerdheid onontbeerlik. - 'n Ander uiters belangrike aspek van wet en profete is dat dit wesenlik toekomsgerig is, maar dan die toekoms as die verwagting van bepaalde handelinge van God in die tyd, dit wil sê handelinge van God wat die karakter

*) Cf. Prof. dr. P. J. Bouman, In de Ban der Geschiedenis, Prisma-Boeken, Utrecht/Antwerpen, s.a. 
van historiese gebeurtenisse sal aanneem wanneer dit in die toekoms verwerklik word. Hierdie toekomsverwagting strek tot aan die einde van die geskiedenis met die koms van die Messias.

2. Die openbaring van God in die Ou Testament is nie net die inhoud van wet en profete nie, maar ook die handeling van God met mense, by uitstek Sy uitverkore volk. Die historiese lotgevalle van die volk Israel, wat met hulle gebeur het, wat hulle gedoen of nagelaat het, is die verhaal van wat God met hulle gedoen het - die verhaal van die wil en voorsienigheid, die seëninge en straf van God. Die geskiedenis van die volk Israel is daarom net so goed openbaring van God en daarom bron van ware kennis aangaande God as wat wet en profete dit is. Die verkondiging van die Ou Testament neem daarom ook in 'n groot mate die vorm aan van 'n dankbare terugblik in die geskiedenis, waaruit vermaning, bemoediging en leiding vir die hede en die toekoms geput kan word.

3. Die openbaring van God in die Ou Testament is gerig op en vind sy vervulling in Christus. In Christus openbaar God Sigself eens en vir altyd. Byna alle ander godsdienste het een of meer groot figure in die vorm van 'n stigter van die godsdiens, 'n wyse wat die sedeleer van die godsdiens ontwerp het en/of 'n verlosser wat die verlossingsweg van daardie godsdiens aangetoon het. Primêr by al hierdie godsdienste is die leer en die lewenswyse wat uit die leer voortvloei, omdat dit die verlossingsweg en die weg tot die geluksaligheid is. Die groot figure word vereer en verkry soms selfs goddelike status, maar word met 'n mitologiese obskuriteit omhul en is relatief onbelangrik in die sin dat die leer en die lewenswyse die belangrikste is; die leer en die lewenswyse sou nog dieselfde kon wees, selfs al sou daar geen groot figuur wees nie of al sou die groot figuur iemand anders wees as wat dit inderdaad was. Daarom is alle godsdienste behalwe die Christelike godsdiens „onhistories" - nie in die sin dat dit buite die tyd staan nie, maar in die $\sin$ dat dit nie aan bepaalde historiese gebeurtenisse gebonde en daarin gegrond is nie.

Hierteenoor is die Christelike godsdiens by uitstek en wesenlik ,histories". Hoe belangrik die leer van die Nuwe Testament (ook die leer van Christus Self) en die lewenswyse wat daaruit voortspruit, ook al mag wees, die Persoon van Christus bly tog primêr. Die verlossing uit sonde en die dood is nie iets wat deur die gehoorsaming aan 'n bepaalde sedeleer verkry word nie, maar word vir die sondaar bewerkstellig deur die geboorte, 
dood en opstanding van die Seun van God wat historiese Persoon, Jesus van Nasaret, op 'n bepaalde plek en tyd gebore is, Sy werk gedoen het, Sy leer verkondig het, vir die sonde van die wêreld aan die kruis gesterf het en met Sy opstanding die sonde en die dood oorwin het. Die belangrikste eukumeniese geloofsbelydenis van die kerk, die Apostoliese Geloofsbelydenis, bestaan dan ook vir die grootste gedeelte uit die opnoem van historiese gebeurtenisse en is in die verlede tyd geformuleer. Die Christus-gebeure is die sentrale feit waarmee die Christelike godsdiens staan of val en alle pogings van die modernisme om hieraan af te doen en die klem van die Persoon van Christus na Sy leer en voorbeeld te verskuif, is ' $n$ aantasting van die wese van die Christelike geloof en godsdiens.

Die geskiedenis-as-verlede-werklikheid is dus vir die Christen van opperste eksistensiële belang. Die Christus-gebeure rig die gemeente terugwaarts in die geskiedenis in na die kruis en die opstanding toe as die grond van die verlossing en die saligheid. Die beslissing van die mens hier en nou ten opsigte van Christus, die antwoord op die Woord van God, het ewigheidsbetekenis; dit kom uit die verlede, van Golgota af, en bepaal die hele toekoms, sowel die toekomstige tyd as die ewigheid, want dit werp die eksistensie van die gelowige die toekoms in tot op die finale punt waar die werk van Christus in Sy wederkoms die finale voltooiing vind. Die wederkoms van Christus is die einde van die geskiedenis, maar dan ook die sinvolle voleindiging van die geskiedenis, omdat dit nie net beteken dat die geskiedenis tot 'n einde kom nie, maar ook (en veral) dat die finale doel as hoogste waarde bereik en verwerklik.

4. Die verkondiging van die Evangelie is altyd 'n verkondiging aan werklike mense in 'n konkrete historiese gesitueerdheid, wat telkens wissel en aan mense 'n nuwe uitdaging stel. Die historiese gesitueerdheid is die ruimte van ons menslike bestaan; dit is ons leefwêreld wat reeds 'n bepaalde gestalte gekry het en waaraan ons gedurig werk om dit te bewaar of te verander. Nou is die geloof in Christus die grond en sin van ons eksistensie en hierdie geloof word gewek en in stand gehou deur die verkondiging van die woord Jesus Christus. Dit beteken die oorbring van een historiese gebeurtenis - hoewel die fundamentele oergebeure van die geskiedenis - in 'n ander historiese gebeure op so 'n wyse dat dit eksistensieel belangrik en sinvol is. Verkondiging wat dit nie doen nie, faal fundamenteel in sy roeping.

5. Die kerk wat reeds bestaan omdat die Woord reeds ver- 
kondig is en die verdere verkondiging van die Woord tot Goddelike roeping het, is self historiese fenomeen. Al moet 'n mens die kerkgeskiedenis op grond van ander beginsels as die wêreldse geskiedenis interpreteer, is die kerkgeskiedenis 'n onderdeel van die groter geskiedenis-as-verlede-werklikheid. Die kerkgeskiedenis kan nie losgemaak word van die politieke, kuns- ekonomiese ens. geskiedenis nie en dieselfde beginsels van navorsing geld op al die gebiede.

\section{Filosofiese en Teologiese Probleme in die Besinning oor die Geskiedenis :}

Wanneer ons ons nou bepaal tot die geskiedenis-as-verledewerklikheid, dit wil sê tot die gestaltes wat die mens in die loop van die tyd aan sy leefwerreld gegee het, het ons onmiddellik te doene met die feit dat daar 'n vakwetenskap, die geskiedenisas-wetenskap, is wat hierdie verlede werklikheid tot objek van studie het. Beteken dit nou dat die filosofie, die teologie en die geskiedenis-as-wetenskap dieselfde terrein betree? Wat is die verhouding tussen die drie? In hierdie verband wil ons die volgende probleme na vore bring :

1. Die besinning oor die wesenlike historisiteit van die mens is een van die sentrale en fundamentele temas van filosofiese besinning. Hier gaan dit oor 'n ander voorwerp van studie as waarmee die geskiedenis-as-wetenskap hom besig hou. Die wesenlike historisiteit van die mens is die grond daarvan dat daar 'n geskiedenis-as-verlede-werklikheid is waarmee die geskiedenis-as-wetenskap hom kan besig hou en is tegelykertyd die grond van ons belangstelling in die geskiedenis-as-verlede-werklikheid. Die geskiedenis-as-wetenskap het egter nie die historisiteit van die mens tot voorwerp van studie nie, maar gaan van die (meesal versweë) veronderstelling daarvan uit. Dat die historikus besef hiervan en insig hierin moet hê, is egter noodsaaklik : Geskiedenis-as-wetenskap hou hom net met die menslike verlede (dit wil sê menslike strewe en handeling, mislukking en sukses, politiek, kuns, godsdiens, denke, oorloë ens. - wat ons saamvat onder die term ,leefwêreld") besig en nie-menslike elemente (byvoorbeeld natuurverskynsels) het alleen betekenis in so verre dit betekenis vir die menslike leefwêreld het. Om hierdie rede is die mensbeskouing van die historikus van wesensbelang; die aard van sy geskiedskrywing en geskiedenisinterpretasie hang hiervan af. Soos sy mensbeskouing is, so is ook sy geskiedenisbeskouing en so is ook sy geskiedskrywing. Die fout wat die meeste historici maak, is om die historiese ver- 
loop as die gevolg van 'n aantal meganiese faktore (natuurverskynsels, ekonomiese verhoudinge, sosiale kragte ens.) te sien waarby ' $n$ misterieuse, irrasionele faktor - vaagweg aangedui as die "psychological factor" of "human nature" - as 'n onberekenbare $X$ gevoeg moet word. Dit is verkeerd, omdat selfs die hooggeroemde "historiese feite" nie eers vasgestel kan word sonder om dit te sien in die lig van wat die wese van die mens is nie.

In hierdie opsig is die filosofiese besinning van wesensbelang vir die geskiedenis-as-wetenskap, maar die filosofie speel hièr die rol van hulpwetenskap vir die geskiedenis-as-wetenskap en die een betree nie die objeksgebied van die ander nie.

Hoewel die teologiese mensbeskouing selde in hierdie verband te berde gebring word, moet ons nie dink dat dit hier buite rekening gelaat, kan word nie. Dit is geensins die geval.

Die wysgerige antropologie is as selfstandige afdeling van die wysbegeerte nog geen halwe eeu oud nie, maar in die halwe eeu het 'n stryd oor die mensbeskouing ontbrand wat nog geensins beslis is nie en in al sy felheid voortgaan. Die wortels van hierdie stryd gaan 'n goeie vyf eeue terug na die aanbreek van die moderne tyd, waar een van die belangrikste verskynsels die opkoms van die natuurwetenskappe was. Nog drie eeue daarna geld die Christelike mensbeskouing feitlik vanselfsprekend: Die mens is die enigste skepsel wat na die beeld van God geskape is en beklee daarom ' $n$ unieke posisie in en staan teenoor die ganse skepping van God en het daarom 'n waarde en waardigheid wat alleen relatief ten opsigte van God is. Ten opsigte van die res van die skepping is die waarde en waardigheid van die mens absoluut en onreduseerbaar. Die mens is ook wesenlik sondaar en daarom in die hele skepping die enigste sedelike wese, dit wil sê wese met selfbewussyn, met die vermoë om tussen goed en kwaad te onderskei, wese met waarde- en normbesef en met die besef van verpligting tot gehoorsaamheid aan die waardes, wese deur God geroepe om God op aarde te verheerlik - 'n roeping wat beide bestel word en moontlik gemaak word deur die soendood van Christus aan die kruis en die werking van die Heilige Gees. Teen die 18de eeu word God in die deisme op die agtergrond geskuif en kry die mens ' $n$ intrinsieke waarde en waardigheid wat geen transendente verankering behoef nie. Maar dit is asof hierdie las te swaar is vir die mens om te dra sonder 'n verankerdheid buite homself. Waar hy die verankering in God verloor het, soek hy dit in die benede-menslike. Nog in diẻ 
18de eeu begin die ver-naturalisering van die mens wat in die $19 \mathrm{de}$ eeu en aan die begin van die twintigste eeu sy toppunt bereik. Hierin word die mens gereduseer tot 'n benede-menslike vlak - die mens as geheel en in sy wese is produk van die natuur, deel van die natuur en geheel en al verklaarbaar vanuit die natuur. Die deel van die natuur wat veral na vore gebring is, is die dier, sodat die mens veral terme van die dierlike resloos verklaarbaar is. Die mens as deel van die natuur is onderhewig aan die prosesse, wette en kragte van die natuur en is ewe min en ewe veel uniek as wat 'n itermagô uniek is. Die vryheid van die mens wat sy verantwoordelikheid voor God impliseer, sy waardebesef en die sedelike onderskeidingsvermoë, sy waarde en waardigheid as skepsel na die beeld van God - in kort al die gedagtes wat die wese van die Christelike mensbeskouing uitgemaak het en die grondslag van die Westerse kultuur gevorm het, word wegverklaar as epiphenomena, neweverskynsels van die wesenlike dierlike mens wat (gewoonlik in terme van evolusie en natuurlike drifte, drange en behoeftes) wegverklaar kan word. Die teologie wat kontemporêr met hierdie verloop van sake bestaan, maak grootliks die indruk van 'n innerlike lamheid en onbeholpenheid - so asof die teologie meegesleur word deur 'n stroom wat magtiger as die teologie is en waaroor die teologie tog per slot van rekening niks werkliks te sê het nie. ${ }^{3}$ )

$\mathrm{Na}$ die Eerste Wêreldoorlog kom die teologie in verskillende denkrigtings met groter vertroue en roepingsbewustheid na vore as wat die geval vir baie, baie jare was. Tegelykertyd word veral vanuit die psigiatrie 'n mensbeskouing geinnisieer wat die wysgerige antropologie as selfstandige gebied na vore laat tree en in die stryd teen die naturalisme aanknoop. Ook is daar van die kan van wetenskaplikes in die algemeen 'n groter bereidheid om te luister na die nuwe stemme - beide teologies en filosofies, terwyl teologie en filosofie ook op allerhande wyses voelhorings na mekaar uitstoot. Daarmee kom die probleem van die mensbeskouing vol in die brandpunt van die diskussies van. die 20ste eeu te staan.

Die mensbeskouing self is nie voorwerp van studie van die geskiedenis-as-wetenskap nie, maar dit is noodsaaklike vooronderstelling en voorarbeid vir die geskiedenis-as-wetenskap. Die historiografie van die afgelope twee eeue weerkaats dan

3) Vir 'n kort maar deeglike oorsig oor wat hier gesê is, kyk Michael Landmann, Philosophische Anthropologie, Sammlung Göschen Band 156/ 156a, 2. durchgesehene Aufl., Walter Gruyter, Berlin 1964. 
ook hierdie stryd om die mens, soos duidelik te sien is in Vico wat geskiedenis 'n volslae menslike aangeleentheid maak, die 19de en 20ste eeue met hulle sterk naturalistiese strominge asook die teenkant wat vanaf die einde van die 19de eeu na vore tree. Trouens, die stryd om die geesteswetenskappe, waarmee die hele probleem van die mensbeskouing ten nouste gemoeid is, begin teen die einde van die 19de eeu juis met figure soos Windelband, Rickert en Dilthey op die werk van die geskiedenis-as-wetenskap.

2. Kortliks wil ons hier daarop wys dat die geskiedenis-aswetenskap ook hulpwetenskap vir die filosofie en teologie is. Die geskiedenis van die wysbegeerte is een van die belangrikste afdelings van die wysgerige studie en geen periode of figuur of denkbeeld van die geskiedenis van die wysbegeerte is behoorlik verstaanbaar sonder die hulp van die geskiedenis-as-wetenskap wat die nodige kennis van die tydsomstandighede lewer nie. Op dieselfde wyse is die geskiedenis-as-wetenskap ook vir die navorsing van die geskiedenis van die teologie en die kerk onontbeerlik.

Ons moet egter op 'n dieper dimensie van hierdie verhouding wys: Die verskillende rigtings van geskiedenis-navorsing en geskiedskrywing hang saam met 'n hele aantal faktore, byvoorbeeld die ontwikkeling van al meer verfynde tegnieke van navorsing en die ontbloting van al meer gegewens. Die belangrikste faktor is egter die verskillende denkrigtings wat die filosofiese agtergrond en fondament van die geskiedenisbeskouing vorm. Verandering in geskiedenisbeskouing bring veranderinge in die navorsing en interpretasie van die verlede mee. Dit is van die uiterste belang vir die teologie in besonder: Die studie van die Ou Testament en Nuwe Testament vorm die grondslag van alle teologiese studie en veranderinge op hierdie terrein werk deur in die geheel van die teologiese wetenskappe en in elke onderafdeling. Nou is daar verskillende teologiese denkrigtings wat hulle invloed op die Ou en Nuwe Testamentiese navorsing uitoefen, maar wat die teoloog baie dikwels uit die oog verloor, is dat rigtings in die geskiedkundige denke ook hulle invloed uitoefen op die navorsing van die Bybel. Op die wyse kan die teoloog in paradyslike onskuld beland waar hy nie wil wees nie. Ons kan as voorbeeld noem die geweldige invloed wat die Marxistiese denke met sy dialekties-materialistiese geskiedenis-interprestasie op die geskiedskrywing van ons tyd uitoefen - 'n invloed wat meestal nie deur de betrokke skrywers eksplisiet erken word nie en waarvan hulle baie dikwels self nie bewus is nie. So kan dit gebeur dat die basies ateïstiese Marxistiese ge- 
skiedkundige beskouings 'n wesenlike bydrae gaan vorm in die navorsing van die Ou en Nuwe Testament. Natuurlik geld wat hier gesê is in nog 'n baie groter mate vir die historiese gedeeltes van die teoligie, soos die kerkgeskiedenis en in minder mate vir die dogmengeskiedenis.

3. Die teologie en filosofie as wetenskappe, elke filosoof en teoloog, elke gedagterigting en gebeurtenis, die inkarnasie van Christus, die tot stand kom van die Bybel, die Christelike godsdiens en die kerk - dit is alles historiese gebeurtenisse, fenomene binne die groot stroom van die historiese verloop. Sedert die begin van die 19de eeu het die historisme die geskiedenis-aswetenskap in so 'n mate ingeneem dat die historistiese standpunt vanselfsprekend in die geskiedeniswetenskap geword het. In wese is die historisme 'n relativisme : Elke historiese gebeure moet binne die samehang van tyd en plek gesien word en is alleen verstaanbaar binne hierdie samehang. Alle aansprake op waarheid en alle geldigheid van waardes en norme moet op dieselfde wyse relatief ten opsigte van plek en tyd gesien word. $\mathrm{Al}$ wat dus wetenskaplik beweer kan word, is dat daar ongeveer 1972 jaar gelede 'n Joodse seuntjie gebore is met die naam van Jesus van Nasaret; Hy het 'n heel interessante lewensloop gehad wat aan die kruis op Golgota geëindig het. Hy het 'n aantal volgelinge gehad wat daarop aanspraak gemaak het dat Hy die Seun van God was, dat Sy kruisdood die versoening van sondes bewerkstellig, dat Hy uit die dood opgestaan het, dat Hy die enigste Verlosser van die mensheid is en so meer. Dat Jesus werklik die Verlosser was en is en so meer kan histories-wetenskaplik nooit beweer word nie. Inteendeel, histories-wetenskaplik moet aangedui word dat daar baie godsdienste ontstaan het en bestaan en dat daar baie verlossers in die verlede geleef het en dat baie leerstellinge as die waarheid aangebied word. Dit is alles histories fenomene wat bestaan, wie se aansprake geldigheid besit en wat verstaan kan word alleen relatief tot 'n benaalde tvd en plek. God, verlossing, waarheid. sonde en so meer is dus alles 'n kwessie van die "supreme coincidence of the place of our birth" (Toynbee) - as ek in Londen gebore is, is ek 'n Anglikaan en as ek in Bombaai is, is ek 'n Buddhis - waarheid is heeltemal subjektief en relatief.

Hierdie relativisme is ' $n$ groot probleem vir die filosoof, veral vir die een wat op die tydlose en algemene geldigheid van sy denkbeelde aanspraak wil maak. Dit is egter 'n wesenlike probleem vir die teologie; dit tas die wese van die Christelike 
godsdiens aan. As Christus nie die enigste en algenoegsame Verlosser van die mensdom is nie en as die waarheid van die Evangelie nie 'n geldigheid het wat nie afhanklik van plek en tyd is nie, is die hart uit die Christelike godsdiens uitgehaal en is die Christelike geloof in sy wese vernietig. Die historiese relativisme is daarom ' $n$ belangrike probleem vir die filosofie, maar dit is lewensbelangrik vir die teologie. En veral die teologie kan die probleem nie omseil nie, want die historiese relativisme is nie net 'n metode van geskiedenisinterpretasie wat ook op die Bybelnavorsing sy invloed uitgeoefen het nie, maar dit het in ons tyd 'n lewensopvatting geword en is ook grootliks die grondslag van die geskiedenis-as-wetenskap. Die verkondiging van die kerk is nog altyd die sterkste wapen teen hierdie relativisme, maar op wetenskaplike vlak moet die teologie met hierdie probleem worstel en 'n antwoord vind. ${ }^{4}$ )

4. Een van die dissiplines van die filosofie is die wetenskapsleer. Die wetenskapsleer het as een van sy take besinning oor die vraag: Wat is wetenskap? Vanaf hierdie algemene vraag moet die wetenskapsleer oorgaan tot die besinning oor die filosofiese probleme van die verskillende vakwetenskappe, dus ook die geskiedenis-as-wetenskap. Dit is een van die twee betekenisse van die term ,filosofie van die geskiedenis", wat ons beter en presieser die kennisleer van die geskiedenis kan noem.") Die kenteoretiese probleem val in twee hoofprobleme uiteen:

4.1. Wat is die voorwerp van historiese studie? Besinning oor hierdie probleem bring ons vanuit 'n bepaalde hoek uit by die historisiteit van die mens, waaroor onder 1 . gehandel is. Die vraag na die wese van die mens is nie ' $n$ probleem van die geskiedenis-as-wetenskap nie, maar is die sentrale probleem van die wysgerige antropologie. Die voorwerp van studie van die geskiedenis-as-wetenskap is die variërende gestaltes wat die mens in die loop van die verlede tyd aan sy lewe en wêreld gegee het, maar die vasstelling van die aard van die voorwerp van studie asook sy beskrywing en interpretasie is afhanklik van en word bepaal deur die beskouing van die wese van die mens. Ons het hier dus te doene met egte filosofiese werk, maar 'n arbeid wat in der mate met die werk van die historikus vervleg is dat iemand soos Jan Romein die filosowe hier wil hok slaan en die gebied

4) Cf. P. S. Drever. ,Historisme en Christendom”, „Hervormde Teologiese Studies. 14de Jf., Afl. I, Julie 1958.

i) An Introduction to the Philosophy of History, Hutchinson's University Library, London, 1951. 
vir die historici alleen in besit wil neem. ${ }^{6}$ )

- 4.2. Die waarheidsprobleem hang ten nouste met die probleem van die voorwerp saam. Die waarheidsprobleem het hoofsaaklik te doene met die fundering en die waarheidsgehalte van die beweringe van die historikus op die vlak van sy, wetenskap. Dit, is dus 'n kcnteoreticse probleem en in hierdis opsig. 'n volledig filosofiese probleem. Die spesifieke aard van die geskiedenisas-wetenskap, sy metode van werk, sy beskouing en interpretasie van die verlede en so meer hang egter af van die voorwerp van andersoek wat aanvaar word, sodat die probleem van die voorwerp en die waarheidsprobleem ten nouste met mekaar saamhang. Ook op die terrein van die waarheidsprobleem is. die werk van die historikus en die filosoof nie net op mekaar aangewys nie, maar selfs in mekaar ineengevleg.

Omdat hierdie punt ten nouste met die volgende saamhang, bespreek ons die teologiese implikasies daar.

5. Die geskiedskrywing, wat die resultaat, van die navorsingswerk van die historikus is, dra in 'n baie groot mate die karakter van 'n verhaal wat vertel word. Die meeste historici neem dan ook die houding in dat hulle - soos Ranke - vertel "wie es gewesen". Oor die algemeen het hulle daarom ook 'n kleintjie dood aan die metafisika, omdat die metafisika - valgens hulle - hom besig hou met allerlei spekulasies oor 'n obskure diepste werklikheid wat vir die geskiedenis-as-wetenskap.nie ter sake is nie; en as die metafisika hom nog besig hou met die geskiedenis, is dit met rampspoedige gevolge, omdat die metafisika altyd 'n aprioriese sisteem op die geskiedenis-as-werklikheid probeer afdruk. Daarom moet die metafisika uit die geskieskrywing weggehou word en dit impliseer dat 'n Christelike heskouing van die geskiedenis ook nie toegelaat kan word nie. want dit is ook 'n vorm van metafisika wat 'n aprioriese sisteem op die geskiedenis-as-werklikheid wil oplê en van buite af voorskrifte-aan die geskiedenis-as-wetenskap wil maak.

Tog is die situasie nie so eenvoudig nie. 'n Bekende historikus soos E. H. Carr kan vir ons as voorbeeld dien. Carr gaan uit sy pad om te bely dat hy geen dieper werklikheid as faktor in die geskiedenis wil aanvaar nie : „Personally, I find it. hard to reconcile the integrity of history with belief in some super-

6) Jan Romein. Tussen Vrees en Vrijheid. Vijftion historische Verhandelingen. E.M. Querido. Amsterdam. 1950; Do., In de Hof der Historie. Kleine Encvelcpedie der theoretische Geschiedenis, F.M. Querido, Amsterdam, 1963. 
historical force on which its meaning and significance depend - whether that force be the God of a Chosen People, a Christian God, the Hidden Hand of the deist, or Hegel's World Spirit. For the purpose of these lectures, I shall assume that the historian must solve his problems without recourse to any such deus ex machina, that history is a game, so to speak, without a joker in the pack". ") Wanneer hy egter die oorsaaklikheidsprobleem behandel, skrywe hy: "The study of history is a study of causes". "The first characteristic of the historian's approach to the problem of cause is that he will commonly assign several causes to the same event". "The true historian, confronted with this list of causes of his own compiling, would feel a professional compulsion to reduce it to order, to establish some hierarchy of causes which would fix their relation to one another, perhaps to decide which cause, or which category of causes, should be regarded in the last resort' or ,in the final analysis' (favourite phrases of historians) as the ultimate cause, the cause of all causes. This is his interpretation of his theme; the historian is known by the causes which he invokes". ${ }^{8}$ ) Hierop kan die filosoof alleen sê : Die historikus wat alle metafisika met groot gebaar by die voordeur uitsmyt, smokkel weer 'n metafisika by die agterdeur in. Sonder hierdie kripto-metafisika kan die historikus nie geskiedenis skrywe nie. Ons kan dan ook nie anders as om met Carr se humoristiese opmerkings saam te stem nie - maar ons moet dit uitbrei na die huidige geslag van historici : „This (die 19de eeu) was the age of innocence, and historians walked in the Garden of Eden, without a scrap of philosophy to cover them, naked and unashamed before the god of history. Since then, we have known Sin, and experienced a Fall; and those historians who today pretend to dispense with a philosophy of history are merely trying, vainly and self-consciously, like members of a nudist colony, to recreate the Garden of Eden in their garden suburb. Today the awkward subject can no longer be evaded". ${ }^{9}$ )

Sodra 'n hierargie van oorsake opgestel word en daar van 'n ,cause of all causes" gepraat word, is dit duidelik dat die historikus probeer om deur te dring na die mees fundamentele grondslae waarop hy die dinamiek van die historiese verloop kan baseer. Die meeste historici (soos Carr ook) staan afwysend teenoor gedagtes soos hierdie - dit is metafisika, dit is vrae na

i) E. H. Carr. What is History? Pelican Books A652, p. 75.

8) O.c., p. 87, pp. 89-90.

9) Id., p. 20. 
'n diepste werklikheid, dit is "ultimate questions" wat die historikus nie kan stel nie en waarin hy nie belangstel nie. Nogtans begeef die historikus hom in hierdie metafisika, miskien sonder dat hy dit besef. Dit is wel waar dat die historikus met 'n onderskeiding van minder en meer gewigtige oorsake hom nog nie in een of ander metafisika hoef te begeef nie; in enige historiese gebeure speel ' $n$ hele aantal faktore mee en dit is baie dikwels duidelik dat een van die faktore verreweg die belangrikste is. Daarmee is ons egter nog nie by die kwessie van die "cause of all causes" en daarmee kan 'n historikus nog nie gekarakteriseer word (soos Carr sê) nie. Ons kry met die „cause of all causes" te make wanneer 'n historikus laat blyk dat dit sy oortuiging is dat al die „voor die hand liggende" oorsake tog nog nie die hele verhaal vertel nie, maar dat ons na die "ware" oorsake dieper moet delf; en sodra ons dieper delf, sien ons dat die "eintlike" of "werklike" oorsaak van 'n persoon se handelinge, 'n toestand of gebeurtenis byvoorbeeld ekonomiese verhoudings of die mag van 'n ideaal of die invloed van 'n groot persoonlikheid of iets dergeliks is. Miskien sonder dat hy dit besef, is die historikus hier besig om blyke te gee van Marxistiese, idealistiese, ens. oortuigings wat op die agtergrond van sy geskiedskrywing lê. Nog minder besef hy dat hierdie stelsels omvattende sisteme is, waarby ook ' $n$ baie definitiewe werklikheidsbeskouing of metafsika ingesluit is. En nog minder sal die historikus gewillig wees om al die besonderhede en konsekwensies van so 'n sisteem vir sy rekening te neem. Dit is ook nie ons bedoeling om hier te beywer dat die historikus wat blyke van so 'n oortuiging gee en daarom op ' $n$ bepaalde wyse gekarakteriseer kan word, beskou moet word as iemand wat homself aan 'n bepaalde metafisika gaan verbind het nie. Wat ons wel beweer - en dit is die probleem wat onder oë gesien moet word - is dat die historikus nie vry van die metafisika staan nie en dat hy in belang van sy eie wetenskap homself rekenskap daarvan moet gee.

Die metafisika is 'n deel van die filosofie en daarom is die inmekaar-loop van filosofie en geskiedenis-as-wetenskap hier weereens duidelik. Maar die saak is nog meer ingewikkeld: „Wat de metafysica zoekt", sê de Vos, ,,is een werkelijkheid, die onvergankelijk, onveranderlijk, eeuwig, het inbegrip van alle waarden, de grond en het doel van al het bestaan is. Dat beteekent echter, zal een godsdienstig mens zeggen, dat de metafysica God zoekt". ${ }^{10}$ ) - ons laat dit daar of de Vos se oordeel korrek

11) H. de Vos. Inleiding tot de Wijsbegeerte, 4de druk, G. F. Callenbach, Nijkerk, 1966, p. 182. 
is of nie - of die metafisika inderdaad God soek en of dit iets anders soek en of dit selfs juis die verloëning van God is. Vir ons doel is dit net nodig dat daar ingesien word dat ons hier nie net met ' $n$ probleem van die filosofie sit nie, ook nie net met 'n filosofiese geskiedkundige probleem sit nie, maar ook met 'n teologiese probleem. Die weë wat hier kruis, is nie net twee nie, maar drie. Die geskiedenis-as-wetenskap kan deur die oorsake-probleem en die interpretasie-probleem die metafisika nie vermy nie, terwyl die metafisika 'n filosofiese probleem is, maar dan 'n filosifiese probleem wat wesenlik met die Godsprobleem te doene het.

Die probleem van die kruising van die drie weë word tienvoudig vererger deur die tendens tot selfgenoegsaamheid en insigself-geslotenheid wat ons by aldrie wetenskappe kry. - 'n karaktertrek wat 'n mens by alle wetenskappe kan onderskei. Van die kant van die geskiedenis-as-wetenskap het ons die onkritiese tendens om alle metafisika oorboord te wil, gooi - onkrities omdat die geskiedenis-as-wetenskap homself so .dikwels nie rekenskap gee van die mate waarin hy noodsaaklik teen die agtergrond van 'n metafisika moet werk nie. Die historikus is so dikwels geneig om een metafisika te verfoei en homself dan maar net in die arms van 'n ander te gee. Historici is dikwels ook onkrities in die opsig dat alle metafisiese stelsels en/of beginsels met een streep weggevee word as metafisika,-sonder. om tussen die een of die ander te onderskei. Op dieselfde wyse. word die Christelike geloof en die geskiedenis-interpretasie wat hieruit voortvloei, weggevee as metafisika. Die historikus, vra. dan verontwaardig: Moet ons terugkeer na die soort geskiedskrywing wat ons met Bossuet en vantevore gehad het? Watter wetenskaplike betekenis het dit om uit uit te gaan. van die. standpunt dat God die geskiedenis bepaal en lei? Watter voordeel het dit om God as „,cause of all causes' ',dus as metafisiese prinsipe te aanvaar liewer as 'n ander metafisiese prinsipe wat wetenskaplik meer regverdigbaar is? Die historikus is dan geneig - soos reeds geblyk het in die verwysing na Jan Romein - om te reken dat hy op die terrein van die geskiedenis-as-wetenskap selfgenoegsaam is en nie nodig het om na enige ander stem te luister nie.

Van die kant van die filosoof gesien is die geregverdigde en noodsaaklike vraag wat gevra moet word die volgende: Is die finale oorsaak waarop die historikus die historiese dinamiek teruggevoer van so 'n aard dat dit die voorwerp van historiese studie, naamlik die leefswêreld van werklike mense van die ver- 
lede, tot reg laat kom? Van hieruit gesien, is die taak van die filosofie 'n kritiese taak wat gerig is op suiwering en verheldering en kan bydra tot fundering. Die filosoof ly egter ewe goed (en meesal nog erger) aan selfgenoegsaamheid en in-sigself-geslotenheid as die historikus. Dan is die filosoof geneig om met 'n onwetenskaplike voorskriftelikheid te begin: Vanuit sy beginsels en insigte ontwerp hy 'n metafisika van die geskiedenis, 'n skema wat hy van buite af op die geskiedenis-as-werklikheid oplê. By hierdie geskiedenis-as-werklikheid rekın hy sommer die hede en toekoms in, sodat hy ook die einde en die sin van die geskiedenis met selfvertroue praat. Waar ons dus met die geskiedenis te doene het, het die filosofie nie net 'n kritiese taak ten opsigte van die geskiedenis-as-wetenskap nie, maar ook baie beslis ten opsigte van sigself.

Hierdie taak van selfkritiek rus ook op die teologie. Van die kant van die teologie gesien, moet die teoloog konstateer en dit ook betreur dat daar vanaf die Renaissance 'n besliste tendens weg van die Christelike geloof en godsdiens is. Dat daar selfs 'n sterk anti-godsdienstige en anti-Christelike streep binne die wêreld van die wetenskap was en is, kan nie ontken word nie. Dit geld ook die geskiedenis-as-wetenskap. Ten opsigte hiervan het die teoloog die taak on die Evangelie ook aan die wetenskaplikes te verkondig en is hy heeltemal geregverdig om die kritiese vraag te stel: Het die geskiedenis-as-wetenskap sedert Vico nie maar net God uit die geskiedenis verban om Hom met 'n mensgemaakte surrogaat, dit wil sê 'n afgod, te vervang nie? Die selftevredenheid, selfgenoegsaamheid en in-sigself-geslotenheid is egter ook 'n sonde van die teoloë. Daarom is hulle maar alte geneig om die skuld vir die afwysende houding van die wetenskaplikes by almal behalwe die teoloë self te gaan soek. Vir die teologie sien ons hier 'n uiters ernstige en belangrike probleem: Dit is maklik om te eis dat wetenskaplikes 'n "Christelike” wetenskap" - in casu 'n „Christelike” geskiedeniswetenskap en geskiedskrywing - moet handhaaf. Dit is ook baie maklik om ontwerpe en voorskrifte vir die geskiedenis-aswetenskap te maak. Maar weet die teoloog behoorlik wat hy eis? Historici is meesal geneig om die Christelike geskiedenisbeskouing as metafisika te verwerp. Wie se skuld is dit dat die Christelike geloof in die oë van wetenskaplikes so dikwels die karakter van 'n metafisika aanneem? Wanneer die teoloog van die Christelike geloof 'n wetenskaplike sisteem maak wat hy aan alles en almal wil oplê, doen hy niks anders as om nog 'n metafisiese sisteem die wêreld in te stuur nie: Hierdie „Christe- 
like metafisika" kom dan te staan naas en in kompetisie met die talle ander metafisiese sisteme. In hierdie wedywering begin die "Christelike metafisika" met 'n agterstand in ons moderne wêreld, omdat hy uiteindelik met die gesag van die Deus dixit he te steun - dit in 'n wêreld wat grootliks wetenskap-gelowig geword het. Dat die wetenskaplike - in casu die historikus die "Christelike metafisika" verwerp, moet ons nie verwonder nie, want die "Christelike metafisika" benader die wetenskap met dieselfde tekortkominge, dieselfde aprioriese konstruksies, ' $n$ baie groter en irriterender aanmatiging en 'n baie geringer aanspraak op wetenskaplikheid as die ander metafisiese konstruksies. - Die kerstening van die wetenskap is nie langs hierdie weg te vinde nie, maar langs die weg van 'n suiwer luister na die Evangelie van die gekruisigde en opgestane Christus en 'n ernstige besinning oor die aard van die Evangelie en van die Christelike geloof. Maar net so noodsaaklik is 'n ernstige besinning oor die aard van wetenskapsoefening. Die teoloog (en dit geld ook die filosoof) moet nie net vanuit sy eie wetenskap na die geskiedenis kyk nie, maar hom as't ware omdraai om vanuit die geskiedenis-as-wetenskap na die teologie te kyk. Eers dan kan die teoloog, die filosoof en die geskiedkundige met mekaar in vrugbare gesprek tree.

Ten slotte moet ons terugwys na die vorige punt. Die beskouing van die voorwerp van historiese studie en die waarheidsbegrip hang ten nouste saam met die metafisiese probleem wat ons hier gestel het. As die grond van die historiese dinamiek - die "cause of all causes" - byvoorbeeld in een of ander vorm van wetmatigheid gevind word (soos die "social physics" van Comte, die psigiese wetmatigheid van Lamprecht, die zoölogiese wetmatigheid van Taine, die sosiale en ekonomiese wetmatigheid van die Marriste, ens.), dan is die voorwerp van historiese studie nie net om te beskrywe „wie es gewesen”, maar dan is die werklike voorwerp van historiese studie die verloop van die wetmatigheid in ' $n$ bepaalde periode. Daarmee hang ook die waarheid van die historikus se uitsprake saam: Die geskiedskrywing sou dan waar wees wanneer dit die historiese gebeure in terme van die wetmatigheid kan interpreteer.

6. Sedert Augustinus het dit vanselfsprekend in die Westerse geskiedskrywing geword om die historiese verloop onder die beeld van 'n lyn te sien. Ons kry allerlei variasies op hierdie beeld, byvoorbeeld die gedagte van die stroom wat nie heeltemal reguit loop nie en ook nie teen 'n konstante spoed loop nie, die beeld van die spiraal, Toynbee se beeld van die strydwa wat reg- 
uit beweeg met draaiende wiele en so meer, maar in al hierdie variasies bly die gedagte van die lyn fundamenteel bepalend. Volgens die liniêre visie verloop gebeurtenisse eendimensioneel opeenvolgend aan mekaar, terwyl verskillende reekse gebeurtenisse ook gelyktydig aan mekaar verloop. Omdat die historiese verloop só geskied, kan gebeurtenisse, omstandighede en toestande later in die tyd analoog wees aan gebeurtenisse, omstandighede en toestande vroeër in die tyd, maar ' $n$ werklike herhaling is nie moontlik nie en 'n terugkeer na die begin is ewe-eens uitgesluit. Elke gebeurtenis en elke stryd is uniek en moet in sigself gesien en bestudeer word. Die liniêre geskiedenisvisie is 'n erfenis uit die Joodse en Christelike godsdienste. ${ }^{11}$ ) Buite die Joodse en Christelike godsdienste word die lewe van die mens en daarmee saam sy geskiedenis na analogie van die wentelgang van die hemelliggame en die sikliese gang van die natuur onder die beeld van die sirkel gesien. ${ }^{12}$ )

Die Christelike geskiedenisvisie ${ }^{13}$ ) is dat die geskiedenis begin by die skepping en sondeval en eindig by die wederkoms van Christus. Die inkarnasie van Christus is die middelpunt wat die geskiedenis in twee dele deel. Dit is nie 'n chronologiese middelpunt nie, maar die singewende middelpunt. Die geskiedenis voor die koms van Christus ontvang sy sin in die feit dat dit heenwys op en heenbeweeg na die koms van Christus. Dit is veral te sien in die Ou Testament, maar ook in die geskiedenis van die Roomse Ryk wat die onbewuste voorbereiding vir die koms van Christus is in die sin dat die omstandighede saamloop om die gunstige klimaat vir die koms van Christus te skep, sodat Christus in ,die volheid van die tyd" gebore is. Die tyd na Christus is die tyd wat rigting en sin ontvang in die gelowige en dankbare terugkyk na die soendood van Christus en die vooruitkyk na die wederkoms van Christus om die lewende en die dode te oordeel. Die tyd tussen die koms en die wederkoms van

11) Die verskil tussen die Joodse en Christelike visie is in die verband van hierdie artikel nie belangrik nie en word daargelaat.

12) Cf. Rudolf Bultmann, „Das Verständnis der Geschichte in Griechentum und im Christentum", in Leonhard Rheinisch. Der Sinn der Geschichte, C. R. Beck. München, s.a.; Arnold Toynbee, An Historian's Approach to Religion, Geoffrey Cumberlege, Oxford University Press. London etc.. 1950, Chapter 1; Karl Löwith, Meaning in History. The theological Implications of the Philosophy of History, The University of Chicago Press, Chicago, 2nd impression 1950.

13) Die beste werke in hierdie verband is Oscar Cullmann, Christus und die Zeit. Die urchristliche Zeit- und Geschichtsauffassung, EVZ-Verlag Zürich, 1962; Do., Heil als Geschichte. Heilgeschichtliche Existenz im Neuen Testament, J. C. Mohr (Paul Siebeck). Tübingen, 1965. Ons kan ook verwys na dr. H. Berkhof, Christus de zin der Geschiedenis, G. F. Callenbach, Niikerk, 1958. 
Christus is 'n interim, 'n tussentyd wat eindig met die finale be-eindiging van die geskiedenis in die wederkoms van Christus. $\mathrm{Di}$ ? wederkoms van Christus is die eschaton, wat die voltooiing van Sy werk met die mens is en daarom ook die einde van die geskiedenis is. Hierdie eschaton is egter nie blote beëindiging nic, maar ook telos, die doel van die geskiedenis omdat dit die hoogste waarde is wat gerealiseer sal word.

Die moderne geskiedskrywing behou die struktuur van die lyn, maar laat vaar die begin- en eindpunt van die lyn. Baie van die wesenskenmerke van die Christelike geskiedenisbeskouing word behou (byvoorbeeld die eendimensionele, onomkombare verloop van die historiese gang, die eenmaligheid en uniekheid van elke gebeure, die beslissende karakter van die hede ten opsigte van die toekoms, die verantwoordelikheid van die mens en so meer), maar die begin in skepping en sondeval, die einde in die wederkoms van Christus en daarmee saam ook Christus as singewende middelpunt van die geskiedenis word laat vaar. Dit beteken dat die Christelike singewing aan die geskeidenis daarmee heen is.

Net soos in die geval van die dinamiek van die geskiedenis, die probleem van die „cause of all causes" wat ons reeds genoem het, word hier ook baie surrogate aangebied. Trouens, wanneer Voltaire in 1756 vir die eerste keer die term ,filosofie van die geskiedenis" gebruik en vir meer as 'n honderd jaar daarna, beteken die term die spekulatiewe besinning oor die sin van die geskiedenis (wat Walsh "speculative philosophy of history" noem). Baie filosowe het hulle aan hierdie spekulatiewe besinning oor die geskiedenis gewaag - Kant met sy „Reich der Zwecke", Hegel met die terugkeer van die "Weltgeist" tot sigself, Marx met die oorwinning van die proletariaat as einde van die geskiedenis en so meer.

Vanuit die geledere van die geskiedenis-as-wetenskap (en ook vanuit die filosofie self) het hierteen 'n opstand gekom wat uitloop op 'n volslae agnostisisme aangaande die sin van die geskiedenis. ${ }^{1+}$ ) Ons kan die hoofsaak van hierdie standpunt in die volgende paar stellinge opsom:

6.1. Die geskiedenis-as-wetenskap staan onder die verpligting waaronder elke wetenskap staan, naamlik om te fundeer

11) Cf. Karl Löwith, o.c.; Raymond Aron, Introduction to the Philosophy of History. An Essay on the Limits of historical Objectivity, transl by George J. Irwin, Weidenfeld and Nicolson, London, 2nd impression 1961. (Franse uitgawe 1938; hersiene uitgawe 1948); Do., De Zin der Geschiedenis, Aula-Boeken, Utrecht, s.a. 
wat hy as ware kennis aanbied. Historiese kennis is alleen fundeerbaar deur die navorsing van die reste wat uit die verlede oorgebly het. Langs hierdie weg is die gedagtes van skepping, paradys en sondeval nie fundeerbaar nie kan hoegenaamd nie as historiese kennis aangebied word nie.

6.2. Wanneer ons van die sin van die geskiedenis praat, vind 'n merkwaardige verskuiwing in die betekenis van die woord „geskiedenis" plaas In sy normale betekenis het die woord betrekking op die verlede, maar as ons van die sin van die geskiedenis praat, betrek ons die hele toekoms van die hele mensheid. Die toekoms is nie navorsbaar nie en val buitendien buite die terrein van historiese ondersoek.

6.3. Dit is nie net prakties nie maar ook prinsipieel onmoontliłs om vanuit die geskiedenis-as-wetenskap 'n aanduiding van die sin van die geskiedenis te gee. Dit is eers moontlik om van die sin van die geskiedenis te praat wanneer ons die geskiedenis kan interpreteer vanuit sy gerigtheid op 'n finale en totale einde, wat tegelyk die hoogste waarde is. Historiese navorsing kan die feitelikheid aandui dat mense in die verlede 'n bepaalde eschaton van die geskiedenis aanvaar het, maar kan nooit aandui dat hierdie eschaton of enige ander werklik die einde van die geskiedenis sal wees nie en ook nie dat dit as hoogste doel nagestreef behoort te word nie. Die geskiedenis-as-wetenskap kan hoogstens binne 'n bepaalde en beperkte terrein betekenisse aandui ${ }^{15}$ ), byvoorbeeld die betekenis van die Kerkhervorming in die geskiedenis van Suid-Afrika en so meer. Die aanduiding van die sin van die geskiedenis val prinsipieel buite die grense van die geskiedenis-as-wetenskap.

6.4. Elke duiding van die sin van die geskiedenis berus op 'n skema van die verloop van die wêreldgeskiedenis. Hierdie skema is nie uit die navorsing van die geskiedenis-as-verledewerklikheid verkry nie, maar berus op ander gronde en is apriories ten opsigte van die historiese werklikheid en word dus van buite af op die historiese werklikheid afgedwing. Die geskiedenis-as-verlede-werklikheid dien dan net as illustrasie van die aprioriese skema, wat wetenskaplik heeltemal onaanvaarbaar is. Buitendien is die bonte verskeidenheid en menigvuldigheid van die verlede onder geen skema in te dwing nie.

Ten spyte van hierdie besware is die geskiedenis-as-

1.5) Die onderskeiding van die term, ,sin" as betrokke op die geheel van die geskiedenis en ,,betekenis" as betrokke op 'n deel van die geskiedenis is willekeurig en word alleen gedoen om verwarring te voorkom. 
wetenskap nie van die probleem van die sin van die geskiedenis ontslae nie. Solank die beskouing van die geskiedenis as liniêre verloop vasgehou word, bly die vrae van die waarvandaan en waarheen in die lug hang. 'n Blote kroniek van gebeurtenisse is nog geen geskiedskrywing nie; die historikus wil die verhaal van die verlede op so ' $n$ wyse vertel sodat ons nie net die feite daarvan het nie, maar veral dat dit vir ons verstaanbaar en betekenisvol is. Om dit te kan doen moet die historikus die vrae van die hoe en die waarom, die waarvandaan en waarheen, vooruitgang en agteruitgang en so meer op die een of ander wyse antwoord.

Waar die vraag na die sin van die geskiedenis deur die historikus met ' $n$ ignoramus beantwoord word, kan die filosoof nie anders as om met hom saam te stem dat dit die enigste moontlike antwoord vir die historikus as historikus is nie. Die voorwerp van studie van die historikus is die verlede en die vraag na die sin van die geskiedenis is nie 'n vraag wat aan die verlede in die eerste plek gestel word nie. Nadere besinning toon ons dat die vraag na die sin van die geskiedenis nie deur die mens gestel word wat meer van die verlede wil weet nie, maar deur die mens wat met eksistensiële plekbepaling besig is. Om sin aan my eie lewe te gee moet ek die vraag beantwoord: Waarheen is ek op weg? In diens van watter waardes stel ek my lewe? Wat is die hoogste waarde wat uiteindelik my lewe sinvol maak? Hierdie vraag is 'n vraag wat uit ons wesenlike toekomsgerigtheid opwel. Maar om hierdie vraag te kan beantwoord, moet ek besef dat ek nie alleen is nie, maar dat my lewe eers sinvol kan wees binne die sinvolheid van die lewe van die groter geheel waarvan ek 'n deel vorm. Die vraag na die toekoms moet dus in die meervoud gestel word en hierdie ons word uiteindelik die ganse mensheid.

Die nood aan 'n sinvolle lewe beteken die nood aan 'n toekoms, maar die vraag na die toekoms word beantwoord deur die beslissing in die hede en die hede is die eindpunt van die verlede. Wanneer ons dan sin in die geskiedenis gaan soek deur agterwaarts te kyk, kan ons die sin nie vind nie. Wanneer ons die verlede sien in die lig van 'n sinvolheid wat ons meen te gewaar, beteken dit dat ons in werklikheid die verlede in lyn ruk met ons siening van die toekoms.

Ons het reeds genoem dat filosowe al dikwels 'n ontwerp van die sin van die geskiedenis onderneem het. Die grond van sulke pogings is die nood van die mens aan 'n toekoms, al het die meeste filosowe hierdie feit nie ingesien nie. As ons die 
probleem egter krities benader, moet die filosoof bely dat hy ewemin as die historikus kan sê wat die eschaton van die geskiedenis is. Net so min as die historikus kan die filosoof die sin van die geskiedenis uit die verlede opdiep. Net so min as die historikus kan die filosoof sê dat Christus die singewende middelpunt van die geskiedenis is. Net so min as die historikus kan die filosoof sê dat die wederkoms van Christus die eschaton van die geskiedenis is - of selfs dat daar enige ander eschaton of enige eschaton überhaupt van die geskiedenis is. Prinsipieel het die filosoof geen grond om te beweer dat die geskiedenis nie oneindig sal voortgaan nie. En as hy op grond van waarskynlikhede moet spekuleer, sal hy in die huidige situasie waarskynlik sê dat die einde van die geskiedenis in 'n atoomoorlog sal aanbreek - wat 'n einde sou wees, maar die geskiedenis volkome sinloos sou maak.

Anders is dit met die teoloog - hy kan wel praat van die eschaton en aandui van watter aard dit sal wees, naamlik die wederkoms van Christus. Die teoloog sê dit egter nie op grond van 'n studie van die geskiedenis of 'n spekulasie oor die toekoms nie. Hy sê dit op grond van die openbaring van God in die Bybel. Daarom is dit geen wetenskaplike uitspraak in die sin wat die historikus of die filosoof die term verstaan nie. Dit is belydenis en verkondiging dat Jesus van Nasaret die Seun van God was, dat Sy kruisdood die algenoegsame boetedoening oor die sonde van die mens is en dat daar geen ander verlosser vir die mens is nie. Daarom is die kom van Christus die sentrale keerpunt van die geskiedenis waarvandaan ons die hele geskiedenis moet verstaan. Dit is die keerpunt na die einde toe - die wederkoms van Christus - wat die bereiking van die hoogste doel en die vervulling van die hele gang van die geskiedenis is.

Hierdie uitsprake van die teoloog is belydenis en verkondiging - ook teenoor en aan die historikus en filosoof. Hier beweeg ons nie op die vlak van wetenskaplike navorsing en rasionalisering nie, maar op die vlak van die oproep van persoon tot persoon, die persoonlike woord en antwoord, wat in die grond van die saak 'n oproep van Persoon tot persoon, die Woord wat roep om 'n antwoord is. En die antwoord is 'n eksistensiële beslissing voor God.

Hierdie beslissing is nie irrelevant vir die geskiedenis-aswetenskap nie. Ons het gesien dat die vraag na die sin van die geskiedenis nie deur die historikus as wetenskaplike gegee kan word nie, maar dat die vraag tog in die lug bly hang. Wanneer 
hy dan die antwoord op die vraag gee, gee hy dit nie as historikus wat aan bepaalde wetenskaplike eise moet voldoen nie, maar as persoon wat eksistensieel sy eie plek moet bepaal, wat oor die sinvolheid van sy eie bestaan moet beslis. Hierdie beslissing werk deur in sy hele geskiedenisbeskouing en geskiedskrywing - wat ons waer voor 'n hele legio probleme plaas wat hier nie ter sake is nie, behalwe díe wat ons reeds hierbo aangestip het. Wat ons hier egter wel wil aandui, is dat daar op hierdie vlak deure oopgaan vir die historikus, die filosoof en dic teoloog. Dit is deure wat vir aldrie belangrik is - sowel persoonlik as wetenskaplik - en dit is deure wat ons nie moet toemaak nie, maar liewer al wyer moet oopstoot. 